\title{
"[Ne] com Unlaf mid scipum" A Summary of the Current State of Research with Regard to Olaf Tryggvason's Assumed Presence at the Battle of Maldon
}

In the fourteenth year of King Æthelred's reign (978 - 1013 and 1014-1016), most likely on $10^{\text {th }}$ or $11^{\text {th }}$ August $991,{ }^{1}$ a sizeable fleet of viking ships sailed into the tidal estuary of the river Pant (today known as the Blackwater) near the town of Maldon. There the host of seaborne attackers appears to have moored their vessels near or at Northey Island whence they proceeded to meet the hurriedly assembled forces of the English defenders. Their subsequent encounter turned out to be one of the most celebrated, best documented, and most frequently discussed battles fought in the British Isles during the Viking Age. Apart from the anonymous alliterative poem usually referred to as The Battle of Maldon, ${ }^{2}$ the dramatic events of 991 are recounted in a significant number of more or less dependable sources including, first and foremost, the roughly contemporaneous Anglo-Saxon Chronicle and the $11^{\text {th }}$-century Vita sancti Oswaldi. Valuable, if not at all times dependable, reports of the said encounter might also be found in several later texts, such as John of Worcester's Chronicon

1 The dating uncertainty springs from the discrepancies in three contemporary obits of the ealdorman Byrhtnoth produced in the monastic houses in Winchester, Ramsey (both of which have $11^{\text {th }}$ August), and Ely (10 ${ }^{\text {th }}$ August).

2 As a rule, the poetic works in Old English bear no titles. The Battle of Maldon is thus an editorial designation which has been seen in use since 1834, following Benjamin Thorpe's first English edition of the poem in Analecta Anglo-Saxonica. Other, now rarely used, titles include The Song of Maldon, Byrhtnoth, Byrhtnoth's Death, and, simply, Maldon. 
ex Chronicis, Henry of Huntington's Historia Anglorum, and the Historia regum Anglorum et Dacorum commonly attributed to Symeon of Durham, as well as two anonymous chronicles compiled at the neighbouring abbeys of Ely (Liber Eliensis) and Ramsey (Chronicon abbatice Rameseiensis), all of which are dated to the $12^{\text {th }}$ century. These are further supplemented by the inexorably concise obits of ealdorman Byrhtnoth and, indirectly, Æthelred's 994 peace treaty with the vikings.

Thanks to this abundance of various source texts as well as the still highly transparent topography of the site, it is not unattainable to at least sketchily reconstruct the presumed sequence of events from more than a thousand years ago. As a result of a high level of the tidal water which separated the yet-tobe combatants, neither of the two sides - the as yet unidentified wicingas (vikings) $^{3}$ and the local defenders of the English soil - was in any way capable of bringing the confrontation to the expected bellicose climax. Likewise, the negotiations between the aged ealdorman ${ }^{4}$ and the unnamed emissary, who boldly demanded that they should wið pam golde grið foestnian (secure truce with gold), ${ }^{5}$ came to a deadlock. ${ }^{6}$ In the end, however - perhaps lured by the enticing perspective of everlasting fame achieved on the field of bat$\mathrm{tle}^{7}$ or drawn by some indefinite strategic objective $(\mathrm{s})^{8}-$ Byrhtnoth allowed

3 The Battle of Maldon. Ed. D.G. SCRAGG. Manchester 1984, 11. 26ff. (hereinafter Maldon...).

${ }^{4}$ It is generally believed that in 991 Byrhtnoth was in his early or mid-sixties. E.D. Laborde convincingly argues that, given the fact that in 956 the son of Byrhthelm is already referred to as $d u x$, he must have been born no later than in the early 930s. For more details concerning Byrhtnoth's date of birth and his family ties, see E.D. LABORDE: Byrhtnoth and Maldon. London 1936, pp. 9-30.

${ }^{5}$ Maldon..., 1. 35.

${ }^{6}$ Maldon..., 11. 25-61.

7 The argument that the ealdorman was driven into battle by a hubristic wish to be immortalised in poetry forms the hub of J.R.R. Tolkien's criticism in The Homecoming of Beorhtnoth Beorhthelm's Son, his dramatic dialogue accompanied by two essays Beorhtnoth's Death and Ofermod, originally published in 1953 in the fifth issue of the academic journal "Essays and Studies by Members of the English Association," Vol. 6, pp. 1-18. One may agree with it today or not, but it cannot be denied that his line of reasoning had a significant impact upon the subsequent publications in one way or another dealing with the motif of heroism in The Battle of Maldon.

${ }^{8}$ Stephen Pollington, for instance, suggests that the reason why Byrhtnoth chose not to let the vikings go without first challenging them into battle was his wish to prevent any further plunder along the south-eastern shores of England. S. Pollington: The Warrior's Way: England in the Viking Age. London 1989, pp. 64-65. It must also be remembered that, at that time, Maldon was the site of a royal mint, a fact that the attackers were doubtlessly aware of. D.M. Metcalf, W. Lean: The Battle of Maldon and the Minting of Crux Pennies in Essex: Post Hoc Propter Hoc? In: The Battle of Maldon: Fiction and Fact. Ed. J. CoOPER. London-Rio Grande 1993, pp. 205-224. Finally, one cannot rule out the possibility that, prior to their coming to Maldon, while they were raiding the other towns, the vikings had taken some important hostages and the ealdorman's wish was to prevent them from sailing back to their Scandinavian 
the attackers to cross the aforesaid causeway, thus seriously reducing his own chances of successful resistance. ${ }^{9}$ Unfortunately, his decision turned out to be pregnant with disastrous consequences for the daring ealdorman who was subsequently victus [...] et gladiis caesus occubuit (defeated and hewn down with swords). ${ }^{10}$ In effect, a considerable part of the English forces hastily withdrew from the theatre of combat ${ }^{11}$ in this way deserting not only their fallen leader, but also those who dutifully chose to stay by the side of his mutilated body. ${ }^{12}$

In the light of what has been outlined above, there could be no doubt that the defensive forces at Maldon were led by the powerful ealdorman of Essex, son of the otherwise unknown Byrhthelm (almost certainly, though, a man of substantial political standing), related through marriage to some of the most prominent families of late- $10^{\text {th }}$-century England..$^{13} \mathrm{He}$ is mentioned by name in more than ten independent documents in one way or another dealing with the events of $991,{ }^{14}$ the only notable inconsistency with regard to the East Saxon nobleman being the variable spellings of his name. ${ }^{15}$ Unfortunately, this cannot be said of the attackers, in whose case the question of actual leadership at Maldon still remains unsettled. Amongst the existing source texts, only five make any mention of particular characters on the viking side, although it must be observed that the said references are very often contradictory with one another, and so it is not always clear whether they should actually be connected with the historical battle of Maldon or not. Nonetheless, named are as many as four individuals: Justin/Iustin[us] (Jósteinn), Gupmund/Guthmund[us] (Guðmundr), Swegen (Sveinn), and Anlaf/Unlaf (Óláfr).

While the identity of the first three figures is still being discussed in the scholarly circles, the case of the fourth - on condition that Anlaf and Unlaf are,

homelands. This way or another, it appears that Byrhtnoth was very much determined — intrinsically or externally — to engage them into a battle.

9 Maldon..., 11. 84-95.

${ }^{10}$ Historia Anglorum, entry for 991. In: Henrici Achidiaconi Huntendunensis Historia Anglorum. Ed. T. ARNOLD. London 1879.

${ }^{11}$ Maldon..., 11. 185-201.

12 Maldon..., 11. 202-325.

${ }^{13}$ Byrhtnoth’s wife, Ælfflæd, was the sister of Æthelflæd, the second wife of King Edmund I (939-946).

14 The texts are to be found in: The Battle of Maldon AD 991. Ed. D. ScragG. OxfordCambridge, MA 1991 (in the original Latin and Old English as well as in their Modern English translations) and Sangen om Slaget ved Maldon. Ed. N. Lund. København 1991 (in Danish).

15 There are as many as ten variations of the ealdorman's name in contemporaneous sources: "Byrhtnoð" (Anglo-Saxon Chronicle MSs A and G, The Battle of Maldon), "Brihtnoð" (Anglo-Saxon Chronicle MSs C, D, E, and F), "Beorhtnoth" (Eadwig the Fair's charter dated 956), "Brithnoð" (Eadwig's charter dated 956, bishop Beorhthelm’s charter dated 957), "Brythnoð" (Edward the Martyr's charter erroneously dated 956), "Brihtnoðus" (Anglo-Saxon Chronicle MS F), "Byrihtnoðus" (Vita Sancti Oswaldi), "Brithnodus" (Ely obit), "Brightnothus" (Ramsey obit), "Byrhtnothus" (John of Worcester's Monachi Chronicon ex Chronicis). 
of course, one and the same person - appears to be somewhat less complicated. It cannot be denied that the foremost candidate here is the future king of Norway Olaf Tryggvason (995-1000), who was at the peak of his viking activity in the early 990s and whose military exploits in, particularly, the British Isles are well documented in numerous sources of varied provenance. ${ }^{16}$ This view has almost uncritically been accepted by a great many historians, both academic and popular, including, amongst many others, Benjamin Thorpe (1834), Gwyn Jones (1973), Simon Keynes (2001), and, more recently, Neil Oliver (2012) and W.B. Bartlett (2016). Not surprisingly, following in their footsteps are also several writers of historical fiction, who seem to take it for granted that Olaf was indeed the chief viking leader (or, at least, one of the leaders) at Maldon. His presence is thus well "attested" in a number of literary works including two historical novels — Frans G. Bengtsson's Red Orm (Röde Orm, 1941-1945) and Elżbieta Cherezińska's I am Haldred (Ja jestem Haldred, 2010) — as well as K.V. Johansen's short story Anno Domini Nine Hundred and Ninety-One (2008).

The assumption that Olaf Tryggvason should be in charge of the Scandinavian raiders at the battle of Maldon is of course highly attractive with regard to the process of building up the narrative layers of a historical novel. However, a careful analysis of the existing source materials does not quite confirm the accuracy of this assumption. When it comes to the actual storyline of the battle itself (and what immediately preceded it), the first and most important text should be the anonymous heroic poem probably composed in the immediate wake of the battle, no later than around the turn of the $10^{\text {th }}$ and $11^{\text {th }}$ centuries. The major problem there, however, is that the sequence of events is presented solely from the viewpoint of the defenders, people who did not necessarily have to be well-informed with regard to the name(s) of those who were in charge of the enemy forces. Despite its fragmented form, ${ }^{17}$ the poet succeeds in naming as many as twenty-four or, depending on the reading, twenty-five combatants on the English side, ${ }^{18}$ but not a single viking. The attackers are

${ }^{16}$ Apart from the numerous $12^{\text {th }}$ - and $13^{\text {th }}$-century sources composed in Norway and Iceland (including the sagas of Olaf Tryggvason attributed to Oddr Snorrason and Snorri Sturluson) as well as the above-listed Anglo-Saxon texts in which the future king of Norway is sometimes identified with Anlaf/Unlaf, Olaf's activity in the British Isles is also reported by Adam of Bremen. Finally, there are the numerous skaldic poems about Olaf Tryggvason (e.g. Óláfsdrápa Tryggvasonar) from the early $11^{\text {th }}$ to the late $12^{\text {th }}$ centuries, many of which came to be preserved in the sagas.

17 With both the beginning and the end missing, what is left consists of only 325 lines of alliterative verse. Donald Scragg, however, argues that probably "relatively little is lost from the end" and no more than some "fifty or so lines" could constitute "the setting of the scene" at the beginning. See D. ScragG: The Battle of Maldon. In: The Battle of Maldon AD 991..., pp. $15-17$.

${ }^{18}$ It is not clear whether Byrhntoth's nephew Wulfmær (Maldon..., 1. 113) is the same person as Wulfmær se geonga (the young) (1. 155), the son of Wulfstan, or not. 
usually referred to by means of various descriptive epithets, such as scelida[s] (sailors), ${ }^{19}$ cesc-here (ash-army, i.e. "army of ashen spears"), ${ }^{20}$ or, rather derisively, hoeðene scealcas (heathen warriors). ${ }^{21}$ The term wicinga[s] (vikings), ${ }^{22}$ repeatedly applied to them by the poet, does not, of course, carry any definite national implications. Nor does the oft-used ethnonym $\operatorname{Den}[e],{ }^{23}$ which at the time (and, especially, from the point of view of the defenders) could have been used with reference to practically any people from Northern Europe whose ships often went back and forth across the North Sea. All things considered, there is absolutely no trace, allusion, or any indirect reference to Olaf (Unlaf/ Anlaf) Tryggvason in the poetic account of the battle of Maldon.

Far more specific in this respect is the Anglo-Saxon Chronicle. According to versions A (Cambridge, Corpus Christi College 173) and G (British Library, Cotton Otho B.ix), on dissum geare com Unlaf mid prim ond hund nigontigon scipum to Stane ond forhergedon pat onytan, ond for ða ðanon to Sandwic ond swa Janon to Gipeswic ond poet eall ofereode ond swa to Moeldune (in this year Unlaf came with ninety-three ships to [Folke]stone, and [they] ravaged about it, and then went to Sandwich, and thence to Ipswich, and [they] overran it all, and so to Maldon). ${ }^{24}$ One could perhaps accept the above account as quite convincing, if it were not for the fact that it is actually to be found under the year 993 (AN. dccccxciii), i.e. two years after Byrhtnoth is generally reported to have died. There are no such dating problems in the other existing versions of the Anglo-Saxon Chronicle (i.e. wherever the battle is actually referred to), although in C (British Library, Cotton Tiberius B.i), D (British Library, Cotton Tiberius B.iv), and E (Oxford, Bodleian Library, Laud Misc. 636) there is no mention of the viking attacks on either Folkestone or Sandwich. Meanwhile, Unlaf turns into Anlaf and is not to be seen in England until three years later when he is said to have com [...] to Lundenbyrig [...] mid iiii ond hundnigontigum scipum (come to London with ninety-four ships). ${ }^{25}$ Interestingly, he is then accompanied by one Swegen (Sveinn), ${ }^{26}$ whose name does not appear in any of the extant sources pertaining to the events of 991 . There is nothing exceptional about the bilingual (English and Latin) version F of the Anglo-Saxon Chronicle (British Library, Cotton Domitian A.viii), whose author probably

19 Maldon..., 11. 45, 286.

${ }^{20}$ Maldon..., 1. 69.

${ }^{21}$ Maldon..., 1. 181.

${ }^{22}$ Maldon..., 11. 26ff.

${ }_{23}$ Maldon..., 1. 129.

${ }^{24}$ The Anglo-Saxon Chronicle A and G, entry for 993. J.M. Bateley: The Anglo-Saxon Chronicle. In: The Battle of Maldon AD 991..., p. 37.

${ }^{25}$ The Anglo-Saxon Chronicle C, D, and E, entry for 991. J.M. Bateley: The Anglo-Saxon Chronicle..., p. 38.

${ }^{26}$ Quite possibly Sveinn Forkbeard (d. 1014), the oldest son of Harald Bluetooth and father of Knut the Great. 
drew heavily upon an older text of E. ${ }^{27}$ The only notable difference there is the absence of both Anlaf/Unlaf and Swegen. Finally, when it comes to the matters of national identity, the attackers are invariably referred to as Danes (densecum mannum in $\mathrm{C}, \mathrm{D}$, and $\mathrm{E}$, deniscan mannum in $\mathrm{F}$ ). ${ }^{28}$

To make the matters more complicated, an entirely different cast of dramatis personae may be found in each of the next three source texts: John of Worcester's Chronicon ex Chronicis, Symeon of Durham's Historia regum Anglorum et Dacorum, and the anonymous Liber Eliensis. According to John of Worcester, in 991, Gipeswic Dani depopulate sunt, quorum duces fuerunt Justin et Guthmund filius Steitan (Ipswich was devastated by the Danes, whose leaders were Justin and Guthmund, the son of Steita). ${ }^{29}$ Almost identical information - both in content and form - could be found in the other two accounts, in each of which the attackers are led by either Justin et Guthmund filius Steytan ${ }^{30}$ or Iustin[us] et Guthmund[us] fili[us] Stectani. ${ }^{31}$ The reason for this concurrence of names is, as is argued by Alan Kennedy, almost certainly the fact that it was upon John of Worcester's text that the other two chroniclers based their narratives, often with practically identical wording and barely noticeable interpolations. ${ }^{32}$ This way or another, there is absolutely no reference to either Anlaf or Unlaf in any of the three afore-quoted source texts.

All the other documents - Vita sancti Owaldi, Henry of Huntington's Historia Anglorum, Chronicon abbatice Rameseiensis, and Byrhtnoth's obits written at Winchester, Ely, and Ramsey - focus primarily upon the military deeds of the heroic ealdorman. The only information that could perhaps shed some light upon the attackers' identity is, once again, their somewhat vague description as "Danes" (respectively, Dani, Dacis, and Dacos). Moreover, the author of Vita sancti Oswaldi makes no mention of any towns or villages which could constitute a point of reference in tracking down the raiders' route prior to their coming to Maldon. According to him, the battle was fought somewhere in oriente huius inclite regionis (in the east of that great land, i.e. England). ${ }^{33}$ Henry of Huntington is only a little bit more precise by informing his readers

27 J.M. Bateley: The Anglo-Saxon Chronicle..., p. 42.

${ }^{28}$ The Anglo-Saxon Chronicle C, D, E, and F, entry for 991. J.M. Bateley: The AngloSaxon Chronicle..., p. 38.

29 JoHn OF WORCESTER: Chronicon ex Chronicis, entry for 991. In: Florentii Wigorniensis Monachi Chronicon ex Chronicis. Part 1. Ed. B. THORPE. London 1848, p. 149.

${ }^{30}$ Symeon of Durham: Historia regum Anglorum et Dacorum, ch. 116. In: Symeonis monachi opera omnia. Vol. 2. Historia Regum. Ed. T. ARnOLD. Cambridge 2012, p. 134.

${ }^{31}$ Liber Eliensis, book II, ch. 62. In: Liber Eliensis, ad fidem codicum variorum. Vol. 1. London 1848, p. 181.

32 A. Kennedy: Byrhtnoth's Obits and Twelfth-Century Accounts of the Battle of Maldon. In: The Battle of Maldon AD 991..., p. 72.

${ }_{33}$ Byrhtferth of Ramsey's Vita S. Oswaldi. In: The Lives of St Oswald and St Ecgwine. Ed. M. LAPIDGE. Oxford 2009, p. 156. 
that the vikings' coming to Maldon was preceded by their attack on Wic, an enigmatic town that historians generally identify as Ipswich. ${ }^{34}$ The least revealing of them all is evidently the Chronicon abbatice Rameseiensis, whose author does not go beyond the rather cryptic information that the Danes partem regni turbaverant (ravaged part of the kingdom). ${ }^{35}$

An intriguing supplement to these battle-related accounts is the aforementioned peace treaty dated to 994 , which mentions by name as many as four characters, including three men on the raiders' side: Anlaf and Justin and Gupmund Steitigan sunu (Anlaf and Justin and Guthmund, the son of Steita). ${ }^{36}$ It appears that the document should be directly linked with Olaf Tryggvason's baptism, which is believed to have been performed in 994 by bishop Alphege $(954-1012) \cdot{ }^{37}$ Under the terms of this treaty, Olaf committed himself not to loot $Æ$ thelred's kingdom and, as is known from a number of sources including Snorri Sturluson's Óláfs saga Tryggvasonar (the sixth narrative of the Heimskringla) and the anonymous Historia Norwegie, he kept his word, concentrating instead upon the consolidation of royal power in his homeland Norway.

Given all this, the problem which remains to be solved is the question of Olaf's supposed presence at the battle of Maldon. The major difficulties are, above all, the discrepancies in the lists of characters named in the surviving source texts referring, directly or not, to Byrhtnoth's last stand (there are in fact as many as four different personal combinations ${ }^{38}$ ) and the rather imprecise dating of the events which may have had anything to do with the said confrontation. Furthermore, there is a conspicuous lack of cohesion with regard to the actual route of the vikings' activity in Britain prior to the battle of Maldon, when even a sketchy approximation could make things less confusing by eliminating some of the more suspicious chronological scenarios. Finally, there is the perhaps unsolvable question of the attackers' "national" identity (provided, of course, that they actually had any awareness of an identity that would go beyond their local allegiances) or, at least, the identity of the man/men who

${ }^{34}$ The Old English noun wic, meaning both "settlement, dwelling" and "wick, bay," is preserved as a suffix (-wic, -wich, -wyck, -wick) in a great number of toponyms in Britain, including Eoforwic (modern day York), Lundenwic (London), Norwich, Ipswich, Sandwich, etc.

${ }^{35}$ Chronicon abbatice Rameseiensis, ch. 68. Chronicon Abbatiae Ramesiensis a Saec. X Usque Ad An. Circiter 1200. Ed. W.D. MaCray. Cambridge 2012, p. 116.

36 The Battle of Maldon. Ed. E.V. Gordon. London 1954, p. 11.

37 See, for instance, F. Stenton: Anglo-Saxon England. Oxford 1988, p. 387. Alphege (Ælfeah, b. 954) was the bishop of Winchester in 984-1006. He was later translated to Canterbury, where he presided until 1011, the year he was captured by the vikings. He was killed the following year and was canonised by Pope Gregory VII in 1078.

38 The combinations are as follows: 1. Anlaf (Anglo-Saxon Chronicle A and G), 2. Unlaf and Swegen (Anglo-Saxon Chronicle C, D, and E), 3. Guthmund and Justin (Chronicon ex Chronicis, Historia regum Anglorum et Dacorum, Liber Eliensis), 4. Anlaf, Justin, and Guthmund (peace treaty). 
initiated the 991 foray. In other words, were the Dani, denisc[e] $m[e n n]$, etc. truly Danes or did they come from some other distant land beyond the North Sea? ${ }^{39}$

Of all these problems, the most significant one is obviously that of the different naming discrepancies that may be found in the Anglo-Saxon texts discussed above. It seems most feasible to suggest that the number of personal combinations could only have arisen from a multiple superimposition of various, not infrequently contradictory reports of the viking activity in Britain in the final decade of the $10^{\text {th }}$ century. It is, after all, rather unlikely that all of the above-named figures - Anlaf/Unlaf, Swegen, Justin, and Guthmund — should jointly lead the attackers at the 991 battle of Maldon. Given their inevitably high social status — at least with regard to Anlaf/Unlaf (Olaf Tryggvason?) and Swegen (Sveinn Forkbeard?) - and the fact that they came to be mentioned in a number of roughly contemporaneous sources, it is difficult to believe that any of them should fight shield to shield against the English defenders as common hersar.

Of all the potential viking commanders at the battle of Maldon, perhaps the least likely candidate appears to be Sveinn Forkbeard, the then ruler of Denmark (986-1014) and Norway (986-995 and 1000-1014) as well as the future king of England (1013-1014). His military activity in the British Isles in the late $10^{\text {th }}$ and early $11^{\text {th }}$ centuries is naturally a well-documented historical fact - he is referred to by name under various raiding circumstances in a considerable number of texts including three versions of the Anglo-Saxon Chronicle (C, D, and E), Snorri Sturluson's Óláfs saga ins Helga, and Adam of Bremen's Gesta Hammaburgensis Ecclesiae Pontificum. However, as far as the above-quoted passages are concerned, his name can only be found in the context of the 994 attack on London (Anglo-Saxon Chronicle C, D, and E). Hence, it looks as if Sveinn's only connection with the dramatic events of 991 stemmed from his being mentioned in the presence of Anlaf, who, in turn, is generally identified with the Unlaf of version A.

Almost as implausible appears to be the supposed presence at Maldon of Olaf Tryggvason, provided, of course, that he should be identified with the enigmatic Anlaf/Unlaf. In fact, all the six documents in which he is mentioned by name are encumbered with a high risk of error. First of all, the entries found in the A and G versions of the Anglo-Saxon Chronicle are not particularly credible on account of the erroneous dating of the battle (AN. dccccxciii) and the assertion that Unlaf should reach the shores of Britain with a rather

39 According to the Historia Norwegie, Olaf Tryggvason's fleet (regardless of whether or not he was actually present at Maldon) consisted of Norwegenses ac Dani, Gautones et Sclauie - "Norwegians and Danes, Geats and Slavs" (ch. XVII, 12). Historia Norwegie. Eds. I. Ekrem, L.B. Mortensen. Transl. by P. Fisher. Copenhagen 2003, p. 92. 
improbable fleet of prim ond hund nigontigon scipum ${ }^{40}$ (ninety-three ships). ${ }^{41}$ What is even more astonishing is that - according to the chronicle versions $\mathrm{C}, \mathrm{D}$, and $\mathrm{E}$ - one year later Anlaf succeeded in assembling an even greater force of iiii ond hundnigontigum (ninety-four) ${ }^{42}$ vessels. This means that not only there was an intriguing annual increase in the size of the viking fleet which amounted to one ship, but that the increase was also curiously correlated with the actual date of the events, that is to say, ninety-three ships in 993 and ninety-four in the following year.

The incorrect dating in version A and, consequently, its later copy G may be interpreted as a scribal error. After all, it is not improbable that the $11^{\text {th }}$-century copyist mistakenly added two $i$ is to the hitherto accurate date $A N$. dccccxci. In reality, however, the issue seems to be a great deal more complicated. Initially, a number of scholars, including Charles Plummer ${ }^{43}$ and E.V. Gordon, ${ }^{44}$ suggested that the 993 entry combined two subsequent accounts of the events dated 991 and 994. A different opinion would later be voiced by Dorothy Whitelock, who, having studied the manuscripts, came to the conclusion that the entire entry for 991, including the problematic passage concerning Unlaf's presence at the battle of Maldon, should be read as correct. ${ }^{45}$ Yet another solution has more recently been put forth by Janet M. Bateley, who, quite convincingly, maintains that the mistake ought to be attributed to the copyist's attempt to squeeze in too much text in the right column, which then made it impossible to correlate the narrative with the dates on the left. ${ }^{46}$ Additionally, she points out the intriguing inconsistency in the subject-verb agreement. Both the name of Unlaf and the pronoun him (in the Old English language common for the third person masculine dative, singular as well as plural) appear alongside singular (com - came, for — went, oferode — overran) and plural (forhergedon — ravaged, ofslogon

40 The Anglo-Saxon Chronicle A and G, entry for 993. J.M. Bateley: The Anglo-Saxon Chronicle..., p. 37.

${ }^{41}$ It is estimated that fully crewed longships could have held up to one hundred men. K. Durham: Viking Longship. Oxford-New York 2002, pp. 34-44. With the ninety-three vessels mentioned in versions $A$ and $G$, even if not fully manned, the viking fleet would have counted more than five thousand warriors, a truly formidable force, equalling or even exceeding the famous "Great Heathen Army" of 865. It is obviously highly unlikely that all the ships should be crowded with men (there would have been plenty of room left for the loot they hoped to obtain), yet even a half of that appears to be a gross exaggeration.

${ }^{42}$ The Anglo-Saxon Chronicle C, D, and E, entry for 991. J.M. BATELEY: The Anglo-Saxon Chronicle..., p. 38.

${ }^{43}$ Ch. Plummer: Two of the Saxon Chronicles Parallel with Supplementary Extracts from the Others. Oxford 1892, p. 173.

${ }^{44}$ The Battle of Maldon. Ed. E.V. Gordon..., p. 10.

45 D. Whitelock (ed. and transl.) with D.C. Douglas and S.I. TuCKer: The Anglo-Saxon Chronicle. London 1961, p. 234.

46 J.M. BAteley: The Anglo-Saxon Chronicle..., pp. 44-45. 
— slew, ahtan — had) verb forms.$^{47}$ This may suggest that the entry for 993 is, in fact, a compilation of two entirely independent narratives which, as a result of the copyist's economising efforts, turned into a somewhat altered narratives recounting the events that took place in either 991 or 993.

Even if we presume that the characters of Anlaf and Unlaf are in truth one and the same person, identical with the future king of Norway, there remains to be considered at least one more possibility. Olaf's appearance at Maldon, which came to be recorded in the A and G versions of the Anglo-Saxon Chronicle, might be no more than a later (although not later than 1013, the terminus ad quem of version A) interpolation made by some determined scribe who found the original entry too concise, and so decided to make it more captivating by supplying the "missing" data. If his intention were to somehow boost the ealdorman's heroic image (recently spoilt by Byrhtnoth's tactical pre-combat blunder, subsequent death and, eventually, profanation of his body ${ }^{48}$ ), an addition of the probably well-known and commonly despised adversary could have been just the right thing to do.

Another notable obstacle which hinders historians from confirming Olaf Tryggvason's coming to Maldon is his absence in the three accounts that transfer the viking leadership to Justin and Guthmund. It must be observed, however, that in John of Worcester's Chronicon the two are primarily associated with the 991 attack on Ipswich. It is therefore not entirely clear whether those who non multo post (not long afterwards) ${ }^{49}$ came up against Byrhtnoth's men actually constituted the entire viking fleet or were only part of it, being, for instance, a loot-laden rear-guard which, perhaps under the sole command of Olaf Tryggvason, on or about $10^{\text {th }} / 11^{\text {th }}$ August, came to rest on Northey Island, i.e. less than two kilometres south-east from the town of Maldon. ${ }^{50}$ The weakest

47 J.M. BATELEy: The Anglo-Saxon Chronicle..., pp. 46-47.

48 According to Liber Eliensis, the vikings caput [eius] cum magno labore secuerunt, quod inde fugientes secum in partiam portaverunt (with great effort managed to cut off his head, which they then took with them to their native land) (book II, ch. 62). Liber Eliensis..., p. 95. In 1769, when the mortal remains of Byrhtnoth, interred in 991 in the newly re-founded abbey at Ely (later relocated into the south-eastern part of the presbytery of the Gothic Cathedral, the so-called West's chapel), were being examined, it was confirmed that his head was indeed severed at the neck with a blunt weapon. For more information concerning Byrhtnoth's burial, see, especially, M. Deegan, S. Rubin: Byrhtnoth's Remains: A Reassessment of his Stature. In: The Battle of Maldon AD 991..., pp. 289-293, and Ł. NeUBAUER: In loco [...] capitis massam cere rotundam: The Need for a Replacement of Byrhtnoth's Missing Head prior to the Ealdorman's Burial in Ely Abbey. In: Motifs through the Ages. Vol. 2. Limbs, Bones and Reopened Graves in Past Societies. Eds. L. Gardela, K. Kajkowski. Bytów 2015, pp. 349-361.

49 John OF Worcester: Chronicon ex Chronicis..., p. 149.

${ }^{50}$ This theory was, to the best of my knowledge, first put forth by Stephen Pollington in his book: S. Pollington: The Warrior's Way..., pp. 33-34. Opinions to the contrary were expressed by, amongst others, Simon Keynes (S. Keynes: The Historical Context of the Battle of Maldon. In: The Battle of Maldon AD 991.., p. 89) and Jakub Morawiec (J. MorAwiEc: 
point of this theory, however, is the fact that the three men - Anlaf, Justin, and Guthmund - are mentioned together in merely one document, the 994 treaty they are reported to have made with King Æthelred. Of course, one thing does not necessarily have to exclude the other. After all, it cannot be ruled out as improbable that the vikings' coming to Maldon was actually part of a wider and more extensive campaign that included Folkestone, Sandwich, Ipswich, and, possibly, other coastal towns in the south-east of England.

Equally problematic are the questions of the route followed by the Scandinavian raiders in the August of 991 and whether the attacks on Folkestone, Sandwich, Maldon, and Ipswich were, in fact, successive stops in the course of the same military operation. Were there any evidence of at least two independent viking campaigns undertaken around the time of the battle of Maldon, ${ }^{51}$ one could perhaps venture to separate the aforementioned accounts, and thus try to mark out Unlaf's/Anlaf's gory trail of destruction. Unfortunately, most of the existing narratives tend to overlap in the key passages, each time bearing witness to the devastation of Ipswich (Anglo-Saxon Chronicle A, C, D, E, and G, Chronicon ex Chronicis, Historia Anglorum, as well as Historia regum Anglorum et Dacorum), which naturally implies but does not provide any firm evidence - that they all actually deal with one and the same event.

All things considered, it must be concluded that, as of yet, the question of Olaf Tryggvason's coming to Maldon in 991 must remain unanswered. It is, nonetheless, believed that the above arguments do not definitely prejudge his absence in the battle, but only demonstrate that, given the current state of our knowledge, any attempt (strictly academic, literary, cinematic, or other) to place him in the context of Byrhtnoth's last stand should be destined to fail from the start. In other words, the future king of Norway may have, perhaps, led the hoeðene scealcas (heathen warriors) ${ }^{52}$ in what came to be one of the best documented military encounters in Viking Age Britain, yet until some

Niektóre sporne problemy dotyczace życia i działalności Olafa Tryggvasona. In: Świat Stowian wczesnego średniowiecza. Eds. M. DworaczyK, A.B. Kowalska. S. MoźDzioch, M. RęBKowsKi. Warszawa 2006, p. 592).

51 The suggestion that there were, perhaps, more than one viking contingent raiding the coastal towns in England around the summer of 991 might be found in, for instance, Ian Howard's book: I. HowARD: Swein Forkbeard's Invasions and the Danish Conquest of England, 991-1017. Woodbridge 2003, p. 36. This view seems to be supported by the Liber Eliensis, whose anonymous author claims that Fiebat siquidem eo tempore frequens inruptio Danorum in Angliam quam, diversis in locis navigio venientes, graviter devastabant (there were at the time several Danish attacks on England, which the [Danes] gravely devastated, coming to various places by ship) (book II, ch. 62). Liber Eliensis..., p. 180. It is very tempting to conclude that they were all part of the same campaign, but there is, unfortunately, not enough evidence to take this assumption for granted.

${ }^{52}$ Maldon..., 1. 181. 
new evidence is found (which does not, however, seem to be very likely), placing him in the heat of combat should only be understood as someone's wishful thinking and overinterpretation of the existing textual sources.

\section{References}

\section{Primary sources}

Adam of Bremen: Gesta Hammaburgensis Ecclesiae Pontificum. Ed. and transl. by F.J. Tschan. New York 1959.

The Battle of Maldon. Ed. E.V. Gordon. London 1954.

The Battle of Maldon. Ed. D.G. SCRAGG. Manchester 1984.

Byrhtferth of Ramsey's Vita S. Oswaldi. In: The Lives of St Oswald and St Ecgwine. Ed. M. LAPIDGE. Oxford 2009.

Chronicon Abbatiae Ramesiensis a Saec. X Usque Ad An. Circiter 1200. Ed. W.D. Macray, Cambridge 2012.

Florentii Wigorniensis Monachi Chronicon ex Chronicis. Part 1. Ed. B. ThOR PE. London 1848. Henrici Achidiaconi Huntendunensis Historia Anglorum. Ed. T. ARnold. London 1879.

Historia Norwegie. Eds. I. Ekrem, L.B. Mortensen. Transl. by P. Fisher. Copenhagen 2003. Liber Eliensis, ad fidem codicum variorum. Vol. 1. London 1848.

Óláfs saga Tryggvasonar af Oddr Snorrason munk. Ed. FINNUR Jónsson. Copenhagen 1932.

Sangen om Slaget ved Maldon. Ed. N. Lund. København 1991.

SNORRI Sturluson: Óláfs saga ins Helga. Købehavn 1965.

SNORri Sturluson: Óláfs saga Tryggvasonar. In: Heimskringla. Vol. 1. Ed. BJARni Aðalbjarnarson. Reykjavík 1941.

Symeonis monachi opera omnia. Vol. 2. Historia Regum. Ed. T. Arnold. Cambridge 2012.

\section{Secondary sources}

Bateley J.M.: The Anglo-Saxon Chronicle. In: The Battle of Maldon AD 991. Ed. D. Scragg. Oxford-Cambridge, MA 1991.

Deegan M., Rubin S.: Byrhtnoth's Remains: A Reassessment of his Stature. In: The Battle of Maldon AD 991. Ed. D. SCRAGg. Oxford-Cambridge, MA 1991.

Durham K.: Viking Longship. Oxford-New York 2002.

Howard I.: Swein Forkbeard's Invasions and the Danish Conquest of England, 991-1017. Woodbridge 2003.

Kennedy A.: Byrhtnoth's Obits and Twelfth-Century Accounts of the Battle of Maldon. In: The Battle of Maldon AD 991. Ed. D. ScragG. Oxford-Cambridge, MA 1991. 
Keynes S.: Apocalypse Then: England A.D. 1000. In: Europe around the Year 1000. Ed. P. URBAŃCZYK. Warszawa 2001.

Keynes S.: The Historical Context of the Battle of Maldon. In: The Battle of Maldon AD 991. Ed. D. ScragG. Oxford-Cambridge, MA 1991.

LABORDE E.D.: Byrhtnoth and Maldon. London 1936.

Metcalf D.M., Lean W.: The Battle of Maldon and the Minting of Crux Pennies in Essex: Post Hoc Propter Hoc? In: The Battle of Maldon: Fiction and Fact. Ed. J. Cooper. LondonRio Grande 1993.

Morawiec J.: Niektóre sporne problemy dotyczące życia i działalności Olafa Tryggvasona. In: Świat Stowian wczesnego średniowiecza. Eds. M. DworaczyK, A.B. Kowalska. S. MoźDzIoch, M. RĘBKowski. Warszawa 2006.

NeUbauer Ł.: In loco [...] capitis massam cere rotundam: The Need for a Replacement of Byrhtnoth's Missing Head prior to the Ealdorman's Burial in Ely Abbey. In: Motifs through the Ages. Vol. 2. Limbs, Bones and Reopened Graves in Past Societies. Eds. L. Gardela, K. KajkowsKi. Bytów 2015.

Plummer Ch.: Two of the Saxon Chronicles Parallel with Supplementary Extracts from the Others. Oxford 1892.

Pollington S.: The Warrior's Way: England in the Viking Age. London 1989.

SCRAGG D.: The Battle of Maldon. In: The Battle of Maldon AD 991. Ed. D. ScraGg. Oxford 1991.

Stenton F.: Anglo-Saxon England. Oxford 1988.

The Battle of Maldon AD 991. Ed. D. SCRAGG. Oxford-Cambridge, MA 1991.

TolkiEn J.R.R.: The Homecoming of Beorhtnoth Beorhthelm's Son. "Essays and Studies by Members of the English Association" 1953, Vol. 6.

Whitelock D. (ed. and transl.) with Douglas D.C. and Tucker S.I.: The Anglo-Saxon Chronicle. London 1961.

Lukasz Neubauer ,[Ne] com Unlaf mid scipum”
Podsumowanie aktualnego stanu badań
nad domniemanym udziałem Olafa Tryggvasona w bitwie pod Maldon

Streszczenie

Na przestrzeni ostatnich kilkudziesięciu lat kwestia ewentualnej obecności Olafa Tryggvasona w bitwie pod Maldon poruszana była niejednokrotnie, przede wszystkim przez badaczy brytyjskich oraz skandynawskich. Należy tu jednak zauważyć, iż zazwyczaj były to analizy dość powierzchowne, czy wręcz marginalne, będące jedynie mniej lub bardziej istotnym uzupełnieniem tematyki omawianej w danej publikacji. Wśród potencjalnych uczestników wydarzeń z sierpnia 991 roku, oprócz przyszłego władcy Norwegii, wymienia się jeszcze króla Danii Swena Widłobrodego oraz nieznanych skądinąd Jósteina i Guðmunda. Ponieważ obecność Swena pod Maldon jest przez zdecydowaną większość historyków słusznie kwestionowana, jedyną tak naprawdę historyczną postacią wśród potencjalnych przywódców skandynawskich najeźdźców pozostaje Olaf, co niestety powoduje, iż część historyków — a w ślad za nimi także piszących na temat średniowiecza twórców stricte literackich — właśnie w nim dość 
pochopnie upatruje głównodowodzącego wikingów. Niniejsza praca ma zatem na celu zestawienie dostępnych tekstów źródłowych (oprócz staroangielskiego poematu aliteracyjnego znanego jako Bitwa pod Maldon, są to przede wszystkim różne wersje Kroniki anglosaskiej, a także różnej maści utwory o charakterze historycznym czy nawet hagiograficznym) oraz ich krytyczną konfrontację z powyższą opinią.

Słowa klucze: bitwa pod Maldon, Olaf Tryggvason, Kronika anglosaska, epoka wikingów, rok 991 w Anglii

\section{Lukasz Neubauer}

\section{"[Ne] com Unlaf mid scipum"}

Zusammenfassung des aktuellen Forschungsstandes über die vermeintliche Beteiligung von Olaf Tryggvason an der Schlacht von Maldon

\section{Zusammenfassung}

In den letzten Jahrzehnten wurde die Frage der eventuellen Teilnahme von Olaf Tryggvason an der Schlacht von Maldon mehrfach, vor allem von den britischen und skandinavischen Forschern, aufgegriffen. Anzumerken ist hier jedoch, dass diese Analysen in der Regel recht oberflächlich oder sogar marginal waren und nur als eine mehr oder weniger wichtige Ergänzung zur in einer Publikation behandelten Thematik galten. Unter den möglichen Teilnehmern an den Ereignissen vom August 991 werden neben dem künftigen Herrscher von Norwegen noch der König von Dänemark Sven Gabelbart und die sonst unbekannten Personen wie Jóstein und Guðmund genannt. Da die Anwesenheit von Sven bei Maldon von den meisten Historikern zu Recht in Frage gestellt wird, bleibt Olaf die einzige historische Figur unter den potenziellen Führern der skandinavischen Angreifer, was leider zur Folge hat, dass einige Historiker und ihnen folgend auch die über das Mittelalter schreibenden strikt literarischen Künstler gerade in ihm ziemlich voreilig den Oberbefehlshaber der Wikinger sehen. Der vorliegende Beitrag setzt sich deshalb zum Ziel, die verfügbaren Quellentexte (neben dem altenglischen alliterativen Gedicht, das als Schlacht von Maldon bekannt ist, gehören dazu in erster Linie verschiedene Versionen der Angelsächsischen Chronik sowie unterschiedliche historische oder sogar hagiographische Werke) zusammenzustellen und sie mit der obigen Meinung kritisch zu konfrontieren.

Schlüsselwörter: Schlacht von Maldon, Olaf Tryggvason, Angelsächsische Chronik, Wikingerzeit, 991 in England 